Syntax Idea : P-ISSN: 2684-6853 E-ISSN : 2684-883X

Vol. 2, No. 2 Februari 2020

\title{
KUALITAS PELAYANAN PERPUSTAKAAN PADA BADAN PERPUSTAKAAN DAN KEARSIPAN DAERAH PROVINSI JAWA BARAT
}

\section{Sundawa Bachtiar}

Sekolah Tinggi Ilmu Sosial dan Ilmu Politik (STISIP) Tasikmalaya

Email: sundawabach@gmail.com

\begin{abstract}
Abstrak
Penelitian ini bertitik tolak dari masalah kualitas pelayanan yang masih belum optimal di Perpustakaan pada Badan Perpustakaan dan Kearsipan Daerah Provinsi Jawa Barat. Masalah tersebut muncul akibat masih belum optimalnya pelaksanaan dimensi-dimensi kualitas pelayanan di Perpustakaan tersebut. Tujuan dari penelitian ini adalah untuk menemukan, mengembangkan, dan menerapkan data dan informasi tentang kualitas pelayanan, serta untuk mengetahui hambatanhambatan. Hambatan dalam pelaksanaan kualitas pelayanan. Selain itu juga usaha untuk meningkatkan dan juga mendapatkan gambaran nyata tentang usaha-usaha yang dilakukan. Metode yang digunakan dalam penelitian ini adalah menggunakan metode kualitatif dengan menggunakan teknik pengumpulan data melalui perpustakaan, penelitian lapangan/observasi. Hasil penelitian ini menunjukkan bahwa kualitas pelayanan belum sepenuhnya berdasarkan dimensi-dimensi teori tersebut. Hasil penelitian dilapangan menunjukan bahwa kualitas pelayanan menunjukan intensitas yang tinggi dan member pengaruh terhadap proses pengelolaan perpustakaan pada Badan Perpustakaan Provinsi Jawa Barat
\end{abstract}

Kata kunci: Kualitas Pelayanan, Kearsipan, Perpustakaan

\section{Pendahuluan}

Salah satu hasil Sidang MPR Tahun 1998 adalah lahirnya Ketetapan MPR Nomor XV/MPR/1998 tentang Penyelenggaraan Otonomi Daerah, Pengaturan, Pembagian dan Pemanfaatan Sumber Daya Nasional yang Berkeadilan serta Perimbangan Keuangan Pusat dan Daerah Dalam Kerangka Negara Kesatuan Republik Indonesia. Ketetapan MPR tersebut menjadi landasan diterbitkannya UndangUndang Nomor 22 Tahun 1999 sebagaimana telah diubah dengan Undang-Undang Nomor 32 Tahun 2004 tentang Pemerintahan Daerah dan Dengan kehadiran kedua undang-undang ini, diharapkan akan lebih memberi peluang pada perubahan kehidupan pemerintahan daerah yang demokratis untuk mendekatkan pemerintah dengan rakyatnya, yang pada gilirannya akan meningkatkan kesejahteraan rakyat secara keseluruhan.

Menghadapi fenomena diatas, Pemerintah Provinsi Jawa Barat telah berupaya mengambil langkah secara normatif terkait bagaimana mengimbangi perubahan tersebut. Sejumlah kebijakan telah dilahirkan oleh lembaga-lembaga terkait pemerintah di level Provinsi ini. Khusus respon terhadap pentingnya perubahan pada Organisasi dan Tata Kerja, Pemerintah Provinsi Jawa Barat melalui terbitnya Peraturan Daerah 
Provinsi Jawa Barat Nomor 22 Tahun 2008 tentang Organisasi dan Tata Kerja telah mengatur bagaimana mekanisme Organisasi-organisasi Pemerintah ini dibentuk. Dalam kaitan dengan pembentukan Organisasi dan Tata Kerja tersebut, didalamnya secara khusus dibahas pula tentang Badan Perpustakaan dan Kearsipan Daerah Provinsi Jawa Barat (Bapusipda Jabar) yaitu pada pasal 3 point 11 yang menegaskan bahwa Bapusipda Jabar merupakan Lembaga Teknis Daerah di lingkungan Pemerintah Provinsi Jawa Barat dan dilanjutkan didalam Paragraf 11 tentang Badan Perpustakaan dan Kearsipan Daerah Pasal 24 mengenai Susunan Organisasi Birokrasi Badan Perpustakaan dan Kearsipan Daerah Provinsi Jawa Barat. Dalam susunan Organisasi Badan Perpustakaan dan Kearsipan Daerah tersebut didalamnya terdapat salah satu subbidang Layanan yang secara khusus menjadi pihak yang menangani secara langsung tentang perpustakaan sebagaimana tercantum dalam huruf (e) point 1 pasal 24 ini. Subbidang Layanan Perpustakaan inilah yang menjadi ujung tombak Bapusipda Jabar dalam memberikan pelayanan langsung kepada masyarakat.

Kemudian mengenai rincian bagaimana tugas dan fungsi Badan Perpustakaan dan Kearsipan Daerah ini, diatur dalam Peraturan Gubernur Jawa Barat Nomor 57 Tahun 2009 tentang Tugas Pokok Fungsi Rincian Unit Badan Perpustakaan dan Kearsipan Daerah Provinsi Jawa Barat. Di dalam Pasal 2 Pergub Jabar Nomor 57 Tahun 2009 ini disebutkan bahwa Bapusipda Jabar memiliki tugas yaitu melaksanakan perumusan dan pelaksanaan kebijakan daerah bidang perpustakaan dan Kearsipan. Sedangkan fungsi Bapusipda Jabar, yaitu:

1. Perumusan dan penetapan kebijakan teknis bidang perpustakaan dan Kearsipan daerah.

2. Pemberian dukungan atas penyelenggaraan pemerintah daerah bidang perpustakaan dan kearsipan.

3. Pengkoordinasian dan pembinaan unit Pelaksanaan Teknis Badan (UPTB).

4. Melaksanakan tugas lain dari Gubernur sesuai dengan tugas dan fungsinya.

Pada Bagian Keenam tentang Bidang Layanan dan Otomasi Perpustakaan, pasal 15 Pergub Jabar Nomor 57 Tahun 2009 menguraikan beberapa hal terkait Subbidang Layanan Perpustakaan, yaitu:

1. Subbidang Layanan Perpustakaan mempunyai tugas pokok melaksanakan penyusunan bahan kegiatan teknis dan fasilitasi layanan perpustakaan

2. Dalam penyelenggaraan tugas pokok sebagaimana dimaksud pada ayat (1), Subbidang Layanan Perpustakaan mempunyai fungsi:

a. Pelaksanaan penyususnan bahan kebijakan teknis dan fasilitasi layanan perpustakaan;

b. Pelaksanaan penyususnan dan pengolahan data kegiatan layanan perpustakaan

3. Rincian tugas Subbidang Layanan Perpustakaan:

a. Melaksanakan penyususnan rencana dan program kerja Subbidang Layanan Perpustakaan;

b. Melaksanakan penyususnan bahan kebijakan layanan perpustakaan; 
c. Melaksanakan layanan keanggotaan perpustakaan;

d. Melaksanakan layanan sirkulasi meliputi kegiatan peminjaman dan pengembalian bahan perpustakaan;

e. Melaksanakan layanan rujukan, penyebaran informasi mutakhir, penyebaran informasi terseleksi dan layanan penelususran bahan perpustakaan baik secara manual maupun berbasis teknologi informasi dan komunikasi;

f. Melaksanakan layanan audio visual

g. Melaksanakan layanan perpustakaan melalui internet, multi media, scaning, printing, typing, inhause training dan komputer;

h. Melaksanakan layanan mendongeng (Story Telling);

i. Melaksanakan layanan mengupas buku (book talk);

j. Melaksanakan layanan ekstensi manual melalui mobil perpustakaan keliling dan layanan terpadu perpustakaan;

k. Melaksanakan pembuatan pemetaan titik layanan mobil Unit Perpustakaan Keliling;

1. Melaksanakan pembinaan pemustaka melalui peningkatan pelayanan perpustakaan sebagai Rumah Belajar, Rumah Ilmu dan Pusat Kegiatan Belajar Masyarakat;

m. Membangun jaringan kerjasama (networking) layanan perpustakaan:

n. Melaksanakan kerjasama layanan perpustakaan dalam bentuk silang layan antar perpustakaan (inter library loan) dan tukar menukar bahan pustaka (exchange programme) dengan semua jenis perpustakaan;

o. Melaksanakan layanan hasil analisis kepustakaan berupa resensi dan review;

p. Melaksanakan layanan khusus bagi pemustaka inklusi;

q. Melaksanakan pengolahan dan menyususn statistik layanana perpustakaan meliputi statistik anggota perpustakaan, peminjaman, pengunjung, buku yang dipinjam dan dibaca;

r. Melaksanakan sosialisasi layanan perpustakaan melalui media cetak, elektronik, pameran dan tatap muka;

s. Melaksanakan penyususnan bahan koordinasi kegiatan pelaksanaan pembangunan dan pengembangan layanan perpustakaan berbasis teknologi informasi dan komunikasi;

t. Melaksanakan pelaporan dan evaluasi Subbidang Layanan Perpustakaan;

u. Melaksanakan peyususnan bahan telaahan staf sebagai bahan pertimbangan pengambilan kebijakan;

v. Melaksanakan koordinasi dengan unit terkait;

w. Melaksanakan tugas lain sesuai dengan tugas pokok dan layanannya.

Keberadaan perpustakaan di Bapusipda Jabar ini selain sebagai salah satu bagian dari Organisasi dan Tata Kerja dilingkungan Pemerintah, peneliti merasa perlu juga untuk meneliti tentang fenomena pelayanan pada organisasi Pemerintah ini. Pelayanan adalah bagian konkrit kegiatan Pemerintah yang menyentuh langsung kepada masyarakat. Namun dalam proses memberikan pelayanan ini, tidak jarang masyarakat 
melihat kenyataan yang belum baik atau belum optimal dari kinerja pelayanan organisasi pemerintah seperti pada bidang yang menangani perpustakaan di Bapusipda Jabar ini.

Dari beberapa temuan tentang belum optimalnya pelayanan Subbidang Layanan Perpustkaan di Bapusipda Jabar ini diantanya adalah:

1. Dalam hal transparansi, pelayanan perpustakaan pada Subbidang Layanan Perpustkaan Bapusipda Jabar ini belum bersifat terbuka, mudah dan dapat diakses oleh semua pihak yang membutuhkan dan disediakan secara memadai serta mudah dimengerti. Hal ini terbukti dari penelusuran kebutuhan untuk peminjaman buku terbaru di rak-rak layanan. Buku-buku terbaru pada perpustakaan Bapusipda Jabar masih didominasi oleh buku-buku terbitan lama, sementara buku-buku baru masih tersipan dan terlambat diolah untuk dapat disajikan di rak-rak peminjaman;

2. Masalah akuntabilitas, bahwa pelayanan pada Subbidang Layanan Perpustkaan Bapusipda Jabar belum dapat mempertanggungjawabkan pelaksanaan pelayanannya kepada publik berdasarkan pada ketentuan peraturan perundangundangan yang berlaku. Hal ini dapat dilihat dari minimnya informasi yang dapat diakses masyarakat tentang pertanggungjawaban pelaksanaan pelayanan perpustakaan;

3. Masalah kondisional, yaitu bahwa pelayanan pada Subbidang Layanan Perpustkaan Bapusipda Jabar belum terdapat kesesuaian dengan kondisi terutama antara kemampuan pemberi dan penerima pelayanan. Hal ini dapat terlihat dari masih belum maksimalnya koleksi perpustakaan yang dapat memenuhi tuntutan perkembangan kebutuhan bahan pustaka masyarakat;

4. Hal partisipatif, yaitu bahwa pelayanan pada Subbidang Layanan Perpustakaan Bapusipda Jabar belum mampu mendorong peran serta masyarakat dalam penyelenggaraan pelayanan publik dengan memperhatikan aspirasi, kebutuhan dan harapan masyarakat. Hal ini terlihat pada masih minimnya jumlah pengunjung perpustakaan serta keikutsertaan masyarakat dalam program-program yang diselenggarakan Subbidang Layanan Perpustkaan Bapusipda Jabar;

5. Hal kesamaan hak, bahwa pelayanan pada Subbidang Layanan Perpustkaan Bapusipda Jabar belum optimal dalam hal pelayanan terhadap kelompok masyarakat yang memerlukan pelayanan khusus semacam kaum difable hal ini menimbulkan kesan diskriminasi jika dilihat dari aspek keutamaan kesamaan pelayanan kepada kelompok minoritas;

6. Hal keseimbangan hak dan kewajiban, bahwa pelayanan pada Subbidang Layanan Perpustkaan Bapusipda Jabar belum mempertimbangkan aspek keadilan antara pemberi dan penerima pelayanan publik. Hal ini terlihat pada masalah sebaran jumlah titik pelayanan bagi masyarakat Jawa Barat secara luas.

Berdasarkan masalah-masalah tersebut, maka akan peneliti tuangkan kedalam proposal tesis dengan judul "Kualitas Pelayanan Perpustakaan pada Badan Perpustakaan dan Kearsipan Daerah Provinsi Jawa Barat." 
Istilah pelayanan menurut (Sinambela, 2006) berasal dari kata "layan" yang artinya menolong menyediakan segala apa yang diperlukan oleh orang lain untuk perbuatan melayani. Pada dasarnya setiap manusia membutuhkan pelayanan, bahkan secara ekstrim dapat dikatakan bahwa pelayanan tidak dapat dipisahkan dengan kehidupan manusia.

Menurut (Moenir, 2010) pengertian pelayanan adalah:

Proses pemenuhan kebutuhan melalui aktivitas orang lain yang langsung. Membicarakan pelayanan berarti membicarakan suatu proses kegiatan yang konotasinya lebih kepada hal yang abstrak (Intangible). Pelayanan adalah merupakan suatu proses, proses tersebut menghasilkan suatu produk yang berupa pelayanan, yang kemudian diberikan kepada pelanggan.

Selanjutnya (Lukman, 2000) pelayanan merupakan suatu kegiatan yang terjadi dalam interaksi langsung antara seseorang dengan orang lain atau mesin secara fisik, dan menyediakan kepuasaan pelanggan.

Kualitas pelayanan atau pelayanan prima sangat vital bagi keberlangsungan sebuah perusahaan (Yusuf, 2016).

\section{Metode Penelitian}

Penelitian ini merupakan jenis penelitian lapangan (field research) dengan pendekatan kualitatif. Penelitian kualitatif adalah penelitian yang menghasilkan prosedur analisis yang tidak menggunakan prosedur analisis statistik atau cara kuantifikasi lainnya. Jelas bahwa pengertian ini mempertentangkan penelitian kualitatif dengan penelitian yang bernuansa kuantitatif yaitu dengan menonjolkan bahwa usaha kuantifikasi apapun tidak perlu digunakan pada penelitian kualitatif.

\section{Hasil dan Pembahasan}

\section{Hasil Penelitian}

Pemakai jasa perpustakaan atau disebut juga Pemustaka di Perpustakaan Badan Perpustakaan dan Kearsipan Daerah Provinsi Jawa Barat sering kali mengeluh akan layanan perpustakaan yang buruk. Hal tersebut disebabkan karena fasilitas perpustakaan yang kurang mendukung atau karena faktor pustakawan yang kurang profesional dalam memberikan pelayanan dan cenderung mengabaikan unsur-unsur pelayanan yang baik.

Apabila diukur dari keberhasilannya dalam menyajikan pelayanan yang berkualitas kepada masyarakat pemakainya, Badan Perpustakaan dan Kearsipan Daerah Provinsi Jawa Baratbelum dapat memenuhi standar-standar kualitas pelayanan yang baik. Lengkapnya fasilitas yang ada, besarnya dana yang disediakan dan banyaknya tenaga pustakawan yang saat ini dimiliki ternyata tidak berarti apa-apa bagi perpustakaan tersebut karena perpustakaan tidak mampu menyediakan pelayanan yang berkualitas. 
Bahan-bahan pustaka belum tersedia secara lengkap bagi mereka yang memerlukannya sehingga hal ini pun menambah buruk pelayanan. Badan Perpustakaan dan Kearsipan Daerah Provinsi Jawa Barat belum tanggap terhadap kepentingan penggunaannya, perpustakaan belum menyediakan bahan pustaka yang sewaktu-waktu diperlukan. Kegiatan pelayanan penyediaan bahan pustakapun belum menjadi bagian dari profesi pustakawan di Perpustakaan pada Badan Perpustakaan dan Kearsipan Daerah Provinsi Jawa Barat.

Fungsi pelayanan perpustakaan pun masih menyimpang dari tujuan perpustakaan itu sendiri. Perpustakaan belum dapat memberikan informasi kepada pemustaka, memberikan kesempatan kepada pemustaka untuk mengadakan penelitian sebagai bagian dari fungsi perpustakaan dalam memberikan informasi. Perpustakaan belum dapat memberi kesempatan kepada pembacanya untuk mengadakan rekreasi. Aktivitas seperti membaca novel atau kegiatan-kegiatan lainnya yang dapat membuat pemustaka dapat terhibur. Begitu pula dengan mendengarkan musik dan menonton video belum optimal dilaksanakan.

Sementara itu dari tujuan perpustakaan yang memberikan pelayanan kepada para pembaca, ternyata bahwa bahan pustaka yang telah diolah dan di kumpulkan belum dapat sampai ketangan pembaca secara mudah, bahan-bahan pastaka yang di kumpulkan terutama di maksudkan agar dapat di pakai oleh pengguna masih sulit ditelusuri secara detil dan terkadang suka membingungkan pemustaka pada saat memerlukan bahan pustaka yang ingin dicarinya.

Bahan pustaka yang yang terdapat di Perpustakaan Bapusipda Jabar masih banyak bahan pustaka yang tidak di pakai oleh siapapun dengan alasan apapun, tetapi masih banyah banyak disimpan. Hal ini merupakan kekeliruan besar. Begitu pula dari tingkat kunjungan, Badan Perpustakaan dan Kearsipan Daerah Provinsi Jawa Barat belum banyak dikunjungi masayarakat secara optimal dan bahkan dapat disebut sebagai perpustakaan sakit. Hal ini disebabkan karena belum adanya usaha maksimal menarik para pengunjung agar mereka memakai bahan pustaka di perpustakaan. Usaha-usaha seperti misalnya, dilakukan dengan promosi jasa perpustakaan dengan maksud agar para pengguna tahu tentang bahan apa saja yang dimiliki oleh perpustakaan, fasilitas apa saja yang di berikan oleh perpustakaan, dan saat mana dapat datang ke perpustakaan belum begitu gencar dilakukan. Bentuk usaha-usaha ini, sampai dengan penelitian ini dilaksanakan belum nampak tertuang secara matang sehingga sebaran informasi belum tersampaikan secara luas.

Berkaitan dengan fungsi pelayanan perpustakaan yaitu mempertemukan pembaca dengan bahan pustaka yang mereka minati belum nampak adanya usaha dalam hal pelayanan perpustakaan menyelenggarakan aktivitas tersebut sehingga membuat pembaca belum merasa senang pada saat datang ke perputakaan. Perpustakaan belum berani bersusah payah mencarikan bahan pustaka yang di kehendaki oleh pengguna apalagi jika harus meminjam keperpustakaan lain. Misalnya perpustakaan mencarikan artikel ke perpustakaan lain di dalam negeri, bahkan kalau perlu di perpustakaan lain di luar negeri. 
Mencarikan bahan-bahan pustaka khusus, misalnya seperti pemustaka dari kalangan akademisi yang membutuhkan artikel-artikel ilmiah, ini merupakan kewajiban yang tidak dapat ditolak, namun di Badan Perpustakaan dan Kearsipan Daerah Provinsi Jawa Barathal ini belum dapat dilaksanakan dengan baik. Pemustaka khusus masih merasa kesulitan memperoleh informasi-informasi mutakhir yang dibutuhkan mereka terutama bahan pustaka yang seyogianya dapat dikoleksi berkaitan dengan perkembangan zaman dengan ciri teknologi maju. Padahal sejauh yang kita pahami bahwa pada zaman informasi dan globalisasi ini, masalah jarak bukanlah suatu yang menghalangi untuk memperoleh dokumen. Badan Perpustakaan dan Kearsipan Daerah Provinsi Jawa Barattelah lama memfungsikan dirinya sebagai lembaga yang juga turut mengembangkan pendidikan, namun belum bnayak dari para pengguna dapat memamfaatkan bahanbahan pustaka yang tersedia untuk pengembangan pendidikan baik fisik maupun non fisik.

\section{Pembahasan}

a. Karakteristik Umum Pemustaka di Perpustakaan Badan Perpustakaan dan Kearsipan Daerah Provinsi Jawa Barat

Pengertian umum perpustakaan adalah institusi pengelola koleksi karya tulis, karya cetak, dan/atau karya rekam secara professional dengan system yang baku guna memenuhi kebutuhan pendidikan, penelitian, pelestarian, informasi dan rekreasi para pemustaka.

Berdasarkan hasil wawancara terhadap 20 orang Pemustaka yang terdaftar sebagai anggota dan pengunjung perpustakaan bukan anggota di lokasi perpustakaan Badan Perpustakaan dan Kearsipan Daerah Provinsi Jawa Barat, Jalan Kawaluyaan II No. 4 Kota Bandung, diketahui bahwa kegiatan kunjungan perpustakaan sebagian besar dilakukan oleh penduduk yang berpendidikan mulai dari tingkat taman kanak-kanak hingga perguruan tinggi.

Pengunjung perpustakaan kebanyakan adalah mereka yang memanfaatkan jasa pelayanan untuk tujuan pencarian informasi dan pengayaan bahan bacaan untuk memenuhi tugas-tugas sekolah, kuliah, keperluan kantor dan hanya untuk rekreasi serta kunjungan wisata biasa atau sekedar mengisi waktu luang saja.

Anggota perpustakaan yang sempat ditemui dan diwawancarai oleh peneliti sebagian besar mengaku sebagai pelajar dan mahasiswa, ibu rumah tangga, pekerja, serta pengunjujg lainnya. Adapun guru atau pendamping bagi anak-anak sekolah ditingkat taman kanak-kanak dan sekolah dasar hanya datang dalam waktu-waktu tertentu saja, tergantung dari ada tidaknya prgram kunjungan sekolah tersebut ke perpustakaan. Mereka kebanyakan datang dari daerah sekitar Kota Bandung serta ada pula dari luar Kota Bandung yaitu berasal dari daerah yang lokasinya berbatasan dengan wilayah Kota Bandung.

Dari hasil temuan di lapangan, permasalahan kualitas pelayanan perpustakaan di Badan Perpustakaan dan Kearsipan Daerah Provinsi Jawa 
Baratsangat beragam. Dari hasil penelitian diperoleh gambaran yaitu: kebanyakan pemustaka adalah mereka yang sedang menyelesaikan tugas akhir sekolah atau kuliah dan ada pula yang sedang mencari referensi berkaitan tugas-tugas sekolah mereka. Tujuan kunjungan ke perpustakaan belum didasari oleh kebutuhan karena adanya rasa cinta terhadap buku. Sebagian besar pengunjung perpustakaan yang berhasil diwawancarai oleh peneliti menyebutkan bahwa ketika tidak ada tugas sekolah biasanya pelajar atau mahasiswa tersebut lebih banyak menghabiskan waktu dengan kegiatan lain dari pada membaca atau mengikuti kegiatan di perpustakaan. Sehingga dapat disebutkan bahwa minat baca masyarakat dan keinginan berkunjung keperpustakaan belum didasari oleh minat atau kecintaan terhadap buku. Hasil tersebut sesuai dengan data yang diperoleh dari Bagian Layanan Perpustakaan Badan Perpustakaan dan Kearsipan Daerah Provinsi Jawa Barat.

Berdasarkan catatan Bagian Layanan Perpustakaan Badan Perpustakaan dan Kearsipan Daerah Provinsi Jawa Barat, hampir 80\% pengunjung perpustakaan adalah pelajar dan mahasiswa data keanggotaan berdasarkan catatan sampai dengan tahun 2012, jumlah anggota perpustakaan di Badan Perpustakaan dan Kearsipan Daerah Provinsi Jawa Barat sebanyak 10.425 orang. Dari jumlah tersebut, hanya 10 persen masyarakat umum, 11 persen guru dan tenaga pendidik serta dosen, dan 79 persen lainnya adalah pelajar dan mahasiswa. (Sumber : Bagian Layanan Perpustakaan Badan Perpustakaan dan Kearsipan Daerah Provinsi Jawa Barat).

b. Jumlah dan Keadaan Koleksi Buku Pada Badan Perpustakaan dan Kearsipan Daerah Provinsi Jawa Barat

Dari sekian jumlah koleksi buku yang ada di Badan Perpustakaan dan Kearsipan Daerah Provinsi Jawa Baratsedikitnya telah memenuhi semua kebutuhan koleksi untuk disebut sebagai perpustakaan umum. Data koleksi buku disesuaikan dengan tingkat usia pengunjung yaitu mulai dari anak-anak sampai dengan orang dewasa adalah sebagai berikut:

\section{Tabel 1}

Jumlah Koleksi Buku Perpustakaan Bapusipda Jabar Per Tahun 2012

\begin{tabular}{cccc}
\hline No & Jenis Koleksi & Jumlah Judul & Jumlah Eksemplar \\
\hline 1 & Koleksi buku anak & 254 & 1068 \\
\hline 2 & Koleksi buku remaja & 154 & 1342 \\
\hline 3 & Koleksi buku deawsa & 25.278 & 92.854 \\
\hline 4 & Koleksi Referensi & 254 & 1068 \\
\hline 5 & Koleksi bahan perpustakaan & 139.835 & 273.958 \\
\hline
\end{tabular}

Sumber: Bapusipda Jabar 2012

Dari sekian jumlah koleksi yang dimiliki Perputakaan Badan Perpustakaan dan Kearsipan Daerah Provinsi Jawa Barat, sebagian besar 
koleksi dalam keadaan baik. Namun ada pula koleksi yang sudah rusak dengan keadaan rusak berat, sedang dan ringan.

Jika dilihat tahun penerbitan buku, masih banyak koleksi buku di Badan Perpustakaan dan Kearsipan Daerah Provinsi Jawa Baratdengan tahun terbit lama sampai dengan sepuluh tahun kebelakang dan tahun penerbitan baru sampai dengan tahun 2012.

c. Waktu Kunjungan Perpustakaan

Waktu kunjungan di Badan Perpustakaan dan Kearsipan Daerah Provinsi Jawa Barat dibuka setiap hari dari Senin sampai dengan Sabtu. Khusus hari libur, layanan perpustakaan tutup. Jam berkunjung ke perpustakaan dimulai dari pukul 09.00 WIB sampai dengan 15.00 WIB. Pada jam pelayanan tersebut, sedikitnya ada waktu satu jam layanan tutup untuk istirahat yaitu setiap pukul 12.00. Untuk kunjungan khusus terutama kunjungan bagi rombongan pengunjung yang direncanakan sebelumnya, layanan perpustakaan akan mempersiapakan layanan khusus pula dan disesuaikan dengan kebutuhan pengunjung dengan waktu kunjungan yang variatif selama jam kerja berlangsung.

d. Sarana dan Prasarana Perpustakaan

Dilihat dari sarana yang dimiliki oleh Badan Perpustakaan dan Kearsipan Daerah Provinsi Jawa Baratsedikitnya telah terdapat sejumlah sarana dan prasaran yang mendukung dan memadai. Sarana dan prasarana tersebut meliputi berbagai macam bentuk dan jenis sesuai dengan standar kebutuhan yang ditentukan. Beberapa diantara sarana dan prasarana tersebut terdiri dari sebuah bangunan permanen empat lantai serta jumlah ruangan pelayanan serta property pendukung pada setiap lantainya. Fasilitas parker yang luas, akses jalan masuk yang luas, ruangan-ruangan yang nyaman dan seterusnya.

e. Jumlah Personil Pustakawan dan Pelaksana pada Layanan Perpustakaan

Dalam mewujudkan kinerja yang baik dan pemberian pelayanan kepada masyarakat setidaknya Badan Perpustakaan dan Kearsipan Daerah Provinsi Jawa Barat telah memiliki jumlah personil Pejabat struktural, pejabat punsional dan pelaksana dalam julah banyak, Jumlah tersebut sebanyak 27 orang yang terdiri dari Kepala Bidang, Kepala Seksi, Pejabat Fungsional dan Pelaksana. Keadaan personil di Badan Perpustakaan dan Kearsipan Daerah Provinsi Jawa Barat terdiri dari orang-orang dengan jenjang usia dan pendidikan yang berbeda-beda.

f. Kualitas Pelayanan di Badan Perpustakaan dan Kearsipan Daerah Provinsi Jawa Barat

1) Aspek Transparansi

Pada pembahasana aspek tranparansi ini, akan diuraikan sejumlah keterangan tentang pelayanan perpustakaan di Perpustakaan Umum pada Badan Perpustakaan dan Kerasipan Daerah Pripinsi Jawa Barat. 
Pembahasan tersebut yakni tentang pelayanan yang bersifat terbuka, mudah dan dapat diakses oleh semua pihak yang membutuhkan dan disediakan secara memadai selain mudah dimengerti.

2) Aspek Akuntabilitas

Pada pembahasana aspek akuntabilitas ini, akan diuraikan sejumlah keterangan tentang pelayanan perpustakaan di Perpustakaan Umum pada Badan Perpustakaan dan Kerasipan Daerah Pripinsi Jawa Barat. Pembahasan tersebut yakni pelayanan yang dapat dipertanggung jawabkan dengan ketentuan peraturan perundang-undangan.

3) Aspek Kondisional

Pada pembahasana aspek kondisional ini, akan diuraikan sejumlah keterangan tentang pelayanan perpustakaan di Perpustakaan Umum pada Badan Perpustakaan dan Kerasipan Daerah Pripinsi Jawa Barat. Pembahasan tersebut yakni pelayanan yang dapat sesuai dengan kondisi dan kemampuan pemberi dan penerima pelayanan dengan tetap berpegang pada prinsip efisiensi dan efektivitas.

4) Aspek Partisipatif

Pada pembahasana aspek Partisipatif ini, akan diuraikan sejumlah keterangan tentang pelayanan perpustakaan di Perpustakaan Umum pada Badan Perpustakaan dan Kerasipan Daerah Pripinsi Jawa Barat. Pembahasan tersebut yakni pelayanan yang dapat mendorong peran serta masyarakat dalam penyelenggaraan pelayanan publik dengan memperhatikan aspirasi, kebutuhan dan harapan masyarakat.

5) Kesamaan Hak

Pada pembahasana aspek kesamaan hak ini, akan diuraikan sejumlah keterangan tentang pelayanan perpustakaan di Perpustakaan Umum pada Badan Perpustakaan dan Kerasipan Daerah Pripinsi Jawa Barat. Pembahasan tersebut yakni pelayanan yang tidak melakukan diskriminasi dilihat dari aspek apapun khususnya suku, ras, agama, golongan, status sosial, dan lain-lain.

6) Keseimbangan hak dan kewajiban

Pada pembahasana aspek keseimbangan hak dan kewajiban ini, akan diuraikan sejumlah keterangan tentang pelayanan perpustakaan di Perpustakaan Umum pada Badan Perpustakaan dan Kerasipan Daerah Pripinsi Jawa Barat. Pembahasan tersebut yaitu pelayanan yang mempertimbangkan aspek keadilan antara pemberi dan penerima pelayanan publik.

\section{Kesimpulan}

Berdasarkan hasil analisa peneliti, bahwa kualitas pelayanan di Perpustakaan Bapusipda Jabar belum optimal dan pelu terus ditingkatkan dalam berbagi hal. Dalam pandangan peneliti, menin. gkatnya kualitas pelayanan akan turut serta pula 
meningkatkan kualitas hidup masyarakat. hal tersebut sangat berkaitan erat yaitu apabila perpustakaan maju dengan kualitas pelayanan yang baik maka masyarakat dapat memperoleh informasi yang diperlukan baik pula dan selanjutnya dapat dipergunakan untuk meningkatkan ilmu pengetahuan maupun untuk membantu memecahkan masalah-masalah yang sedang di hadapinya. Bahan-bahan tersebut dikelola menurut suatu sistem tertentu, sehingga masyarakat dapat memperolehnya dengan mudah, cepat dan tepat.

Namun disisi lain dengan banyaknya pengunjung sudah barang tentu akan terjadi buku yang diminati akan berkurang, dan akhirnya terjadi permintaan pesanan. Perkembangan dunia perpustakaan waktu ini menunjukkan perkembangan yang sangat pesat. Hal ini dapat disaksikan dengan munculnya berbagai jenis perpustakaan, baik yang disediakan untuk lingkungan tertentu, maupun untuk masyarakat luas seperti umum.Sudah barang tentu didalam pembinaannya pimpinan perpustakaan di daerah dihadapkan dengan berbagai masalah antara lain landasan hukum yang menjadi titik tolak di dalam pengelolaannya.

Setiap perpustakaan selalu memperoleh kesan atau image, baik yang positif maupun negatif dari berbagai pihak yang selalu berhubungan. Hal ini merupakan konsekuensi logis, mengingat dalam segala aktivitasnya perpustakaan selalu berhubungan dengan berbagai pihak, khususnya dengan anggota perpustakaan.

Perpustakaan merupakan fasiltas pendukung terciptanya kecerdasan masyarakat serta mendukung program suatu masyarakat yang madani. Untuk meningkatkan mutu layanan perpustakaan dengan cara mencari dan menggali potensi yang ada di masyarakat. Sebagai langkah awal yang ditempuh perpustakaan adalah membangun kesadaran petugas pelayanan dalam rangka lebih mendekatkan diri dengan masyarakat.

Jika memerhatikan pada dari aspek teoritik maka aspek teoritik dapat dikatakan bahwa aturan memiliki hubungan atau berpengaruh terhadap kualitas layanan. Semakin baik aturan yang ada semakin fleksibel maka kualitas akan semakin tinggi.

Logika teori dapat dikatakan bahwa aspek organisasi memiliki pengaruh terhadap kualitas pelayanan. Arah hubungan adalah positip, artinya semakin efesien sistem organisasi penunjang pelayanan, semakin mudah dan fleksibel prosedur dan metode yang ada maka kualitas pelayanan akan semakin tinggi.

Dari pernyataan diatas maka dapat disimpulkan bahwa hubungan sarana pelayanan dan kualitas pelayanan adalah positif dan signifikan artinya semakin tinggi/baik/lengkap sarana pelayanan yang digunakan dalam proses pelayanan sehingga menciptakan unsur kemudahan, kecepatan, keakuratan maka semakin tinggi kualitas pelayanan yang diberikan. Signifikan karena teori menyatakan demikian. 
Kualitas Pelayanan Perpustakaan pada Badan Perpustakaan dan Kearsipan Daerah Provinsi Jawa Barat

\section{BIBLIOGRAFI}

Lukman, Sampara. (2000). Manajemen kualitas pelayanan. Jakarta: STIA Lan Press.

Moenir, Ari Sunanda. (2010). Manajemen pelayanan umum di Indonesia. Bumi Aksara.

Sinambela, Lijan Poltak. (2006). Reformasi pelayanan publik: teori, Kebijakan dan implementasi.

Yusuf, Muhammad. (2016). Pengaruh Label Halal Dan Kualitas Pelayanan Terhadap Minat Beli Konsumen Di Alfamart. Syntax Literate; Jurnal Ilmiah Indonesia, 1(3), 30-38. 